Journal of Chemistry and Technologies

UDC 613.2.032.34

EVALUATION OF GERODIETETIC PRODUCT'S FOR ENTERAL NUTRITION PROTEIN VALUE

Dmytro P. Antiushko

Kyiv national university of trade and economics, 19, Kyoto Str., Kyiv, 02156, Ukraine

Received 31 May 2020; accepted 13 September 2020; available online 4 November 2020

\begin{abstract}
The nutrition is the basis of human life, especially in the process of treatment and rehabilitation. That's why the usage of products for enteral nutrition is becoming widespread now. In the presented article materials the protein value of the developed herodietic product for enteral nutrition, which is based of dry soluble mixtures, was estimated. The design and creation of its component composition was carried out basing on modern generally accepted data about the specific metabolic needs of older people. Provided experimental studies were conducted and their results on the content of proteins, fats, carbohydrates, amino acids composition, score of 8 essential and 2 conditionally essential amino acids, including the amino acid score difference factor (AASDF) (21.5\%), the protein component's biological value $(78.5 \%)$ were obtained and presented. Clinical approbation of the developed product's in ready for consumption form (in addition to the usual nutrition diet), conducted in State Institution «Ukrainian National Academy of Medical Sciences Institute of Gerontology n.a. D.F. Chebotarev», was done using an information about an effect on the recovery of protein blood level of people with somatic diseases and injuries, in the postoperative state. The obtained experimental and analytical data give an opportunity to state the optimal ratio of macronutrients (proteins, fats, carbohydrates) in the developed product to the needs of older age groups, the balance of amino acid composition and high biological value of the protein component of the product. Also the obtained results of provided research make it possible to recommend the developed product's consumption for people with high physical and psycho-emotional loads, somatic dysfunctions, diseases and injuries to restore the proper level of protein in blood, in particular, for the elderly aging groups representatives. The consumption of developed product will significantly improve the nutritional needs of the target consumers' category, including with the accelerated metabolism, during periods of treatment and rehabilitation.

Keywords: enteral nutrition; gerodietetic products; protein component; biological value; amino acids; clinical approbation.

ОЦІНКА БІЛКОВОЇ ЦІННОСТІ ГЕРОДІЄТИЧНОГО ПРОДУКТУ ДЛЯ ЕНТЕРАЛЬНОГО ХАРЧУВАННЯ

Дмитро П. Антюшко

Київський національний торговельно-економічний університет, вул. Кіото, 19, Київ, 02156, Україна

Анотація
\end{abstract}

Повноцінне харчування є основою життєдіяльності людини, особливо при лікуванні та реабілітації. У зв'язку з цим застосування продуктів для ентерального харчування зараз стає поширеним. У представленому матеріалі статті проведено оцінку білкової цінності розробленого геродієтичного продукту для ентерального харчування на основі сухих розчинних сумішей, проектування та створення компонентного складу якого здійснювалося на основі сучасних загальновизнаних відомостей про специфіку метаболічних потреб людей старших вікових груп. Проведено експериментальні дослідження та презентовано їх результати щодо вмісту білків, жирів, вуглеводів, амінокислотного складу та скору 8 незамінних і 2 умовно незамінних амінокислот, У т.ч. коефіцієнту його відмінності (КВАС) (21.5 \%), біологічної цінності білкової складової (78.5 \%). 3 дійснено клінічну апробацію впливу від вживання розробленого виробу у готовому до споживання розчиненому стані (додатково до звичайного раціону) на відновлення рівня білка у крові людей із соматичними захворюваннями та травмами, у після операційному стані, що проводилася у Ду «Інститут геронтології ім. Д.Ф. Чеботарьова НАМН України». Одержані експериментальні та аналітичні дані дозволяють констатувати оптимальне співвідношення вмісту макронутрієнтів у продукті потребам представників старших вікових груп, збалансованість амінокислотного складу та високу біологічну цінність білкової складової виробу. Одержані результати проведеного дослідження також дають змогу рекомендувати його споживання людям із високими фізичними та психоемоційними навантаженнями, соматичними дисфункціями, захворюваннями та травмами для відновлення належного рівня білка, зокрема представниками старших вікових груп. Споживання розробленого продукту дозволить значно поліпшити забезпечення нутритивних потреб цільової категорії споживачів упродовж періодів лікування і реабілітації.

Ключові слова: ентеральне харчування, геродієтичні продукти, білкова складова, біологічна цінність, амінокислоти, клінічна апробація.

*Corresponding author: tel.: +38(097)6585150; e-mail: d.antiushko@knute.edu.ua

(C) 2020 Oles Honchar Dnipro National University

doi: $10.15421 / 082017$ 


\title{
ОЦЕНКА БЕЛКОВОЙ ЦЕННОСТИ ГЕРОДИЕТИЧЕСКОГО ПРОДУКТА ДЛЯ ЭНТЕРАЛЬНОГО ПИТАНИЯ
}

\author{
Дмитрий П. Антюшко \\ Киевский национальный торгово-экономический университет, ул. Киото, 19, Киев, 02156, Украина
}

Аннотация

Полноценное питание является основой жизнедеятельности человека, особенно при лечении и реабилитации. В связи с этим применение продуктов для энтерального питания сейчас становится широко распространенным. В представленном материале статьи проведена оценка белковой ценности разработанного геродиетического продукта для энтерального питания на основе сухих растворимых смесей, проектирование и создание компонентного состава которого осуществлялось на основании современных общепризнанных сведений о специфике метаболических потребностей людей старших возрастных групп. Проведены экспериментальные исследования и презентованы их результаты касательно содержания белков, жиров, углеводов, аминокислотного состава и скора 8 незаменимых и 2 условно незаменимых аминокислот, в том числе коэффициента его отличия (КОАС), биологической ценности белковой составляющей. Проведена клиническая апробация влияния от употребления разработанного изделия в готовом к употреблению растворенном состоянии (дополнительно к обычному рациону) на восстановление уровня белка в крови людей с соматическими заболеваниями и травмами, в после операционном состоянии, которая проводилась в ГУ «Институт геронтологии им. Д.Ф. Чеботарёва НАМН Украины». Полученные экспериментальные и аналитические данные позволяют констатировать оптимальность соотношения содержания макронутриентов в продукте потребностям представителей старших возрастных групп, сбалансированность аминокислотного состава и высокую биологическую ценность белковой составляющей изделия. Результаты проведенного исследования также дают возможность рекомендовать его потребление людям с высокими физическими, психическими и эмоциональными нагрузками, соматическими дисфункциями, заболеваниями и травмами для восстановления надлежащего уровня белка, в частности представителями старших возрастных групп. Потребление разработанного продукта позволит значительно улучшить обеспечение нутритивных потребностей целевой категории потребителей в течении периодов лечения и реабилитации.

Ключевые слова: энтеральное питание, геродиетические продукты, белковая составляющая, биологическая ценность, аминокислоты, клиническая апробация.

\section{Introduction}

Optimal nutrition, scientifically substantiated in accordance with the specificity of aging needs, has a great influence on human organism. It is especially important to address fully the nutritional needs for those representatives of elder aging groups, who have high physiological and psycho-emotional loads, metabolic dysfunctions, disorders and traumas. That is why consumption of food products for special medical purposes - enteral nutrition - became widely used in modern practice. This nutrition contains targeted modelled composition of nutritive components to ensure needs in nutrients and to correct smitten physiological processes. Great role in this kind of products is assigned to proteins. One of the most important characteristics, which identify the level of protein conformity to special dietary needs, in particular for older adults, is its biological value.

The analysis of market's current state of these special food products group gives an opportunity to state its dynamic and rapid development [1-5]. Due to the established relevance of the creation of new products for enteral nutrition and basing on analytic data about peculiarities of the older aging group representatives nutritional needs [6-17] the specialists of the Kyiv National University of Trade and Economics (KNUTE) and the State
Institution "Ukrainian National Academy of Medical Sciences Institute of Gerontology n. a. D.F. Chebotarev" have developed and patented the gerodietetic dry soluble product for enteral nutrition [15]. It is characterised by following components content: maltodextrin monodisperse $(25.00 \mathrm{~g})$, glucose $(21.50 \mathrm{~g})$, protein concentrate, manufactured from dairy whey WPC-80 (20.00 g), omega-3 polyunsaturated fatty acids in casein matrix (the content of omega- 3 fatty acids is more than $90 \%)(10.50 \mathrm{~g})$, fructose $(10.00 \mathrm{~g})$, dietary fiber $(5.40 \mathrm{~g})$, food starch $(4.00 \mathrm{~g})$, l-glutamine $(2.00 \mathrm{~g}), \mathrm{l}$ - methionine $(0.50 \mathrm{~g})$, l- tryptophan $(0.30 \mathrm{~g})$, ascorbic acid $(0.25 \mathrm{~g})$, ginseng root extract $(0.20 \mathrm{~g}), \mathrm{l}$ - tyrosine $(0.10 \mathrm{~g})$, glucosamine $(0.10 \mathrm{~g})$, creamery calcium $(0.07 \mathrm{~g})$, coenzyme $\mathrm{Q}_{10}$ (37 mg), magnesium hydrophosphate (35 mg), calciferol (6 mg), $\beta$-carotene $(5 \mathrm{mg})$, riboflavin (2 $\mathrm{mg}$ ), pyridoxine ( $2 \mathrm{mg}$ ).

It is prescribed, that the preparation of the developed product for consumption (usage) should be carried out by dissolving a portion of the dry mixture $(50 \mathrm{~g})$ in $200 \mathrm{~cm}^{3}$ of boiled water at a temperature of $15-40^{\circ} \mathrm{C}$ (an additional increase of the water amount on $40 \mathrm{~cm}^{3}$ (depending on the preferences of consumers) is possible). The consumption of the developed gerodietetic product is recommended for elderly persons, especially those, who have high physical loads, 
emotional stresses, different somatic traumas and injuries.

Purpose and objectives of the research. The purpose of this study was to estimate protein component of the developed gerodietetic product for enteral nutrition biological value effectiveness. Thus, to achieve this purpose it was necessary to solve the following tasks: to research the content of macronutrients in the developed product, their ratio, to analyse amino acids content, to estimate biological value of the product's protein component, to provide clinical testing of the developed gerodietetic product's consumption functional effectiveness.

\section{Materials and methods}

The research object was the developed gerodietetic dry soluble product for enteral nutrition [18]. Dry soluble product for enteral nutrition "Peptamen", manufactured by Nestle corporation (Switzerland), was chosen as a control sample. It has similar recommendations for usage. It was realized in tin cans with a plastic lid. The components of this product (mentioned in its labelling) are maltodextrins, enzymatically hydrolyzed dairy whey and soy proteins, sucrose, fructose, medium chain triglycerides, potato starch, soybean oil, soy lecithin, calcium carbonate, sodium phosphate, magnesium chloride, choline bitartrate, flavoring, identities natural (vanillin), potassium phosphate, sodium ascorbate, magnesium citrate, carnitine, taurine, niacin, zinc sulfate, pyridoxine hydrochloride, retinol acetate, thiamine, riboflavin, folic acid. Sampling and preparation of dry soluble products samples for research were carried out by random sampling in accordance with all necessary norms.

While carrying out experiments following methods were used: protein content was determined by the Kjeldahl method, lipids - by the Soxlet, carbohydrates - by the Bertrand method. The content of amino acids was identified by the liquid-column ion-exchange chromatography method using the automatic analyzer of amino acids AAA 400 ("Ingos-Laboratory Instruments", Czech Republic) [19; 20]. Fractionation of amino acids into individual ones was made on a chromatographic column, filled with an ion exchanging resign Ostion LG FA. The replication of all experiments was quintuple, of analyzes - triple.

Amino acids score of researched product was calculated basing on the content of each essential amino acids residues in relation to its master sample values, which are developed in accordance with the recommendations of the FAO/WHO profile committee specialists [21].
The protein component's biological value was assessed by using the amino acid score difference factor $(A A S D F)$. It was calculated basing on the results of comparing with the content of ideal one (according the recommendations of $\mathrm{FAO} / \mathrm{WHO}$ expert committee specialists [22] and using the following formula (22-26):

$$
B V=100-A A S D F=100-\sum \Delta \mathrm{RAAS} / \mathrm{n}
$$

where $B V$ - the biological value of product protein component, \%;

AASDF - the amino acid score difference factor, $\%$

$\sum \triangle R A A S$ - the ratio of each essential amino acid (EAA) score to the minimal essential amino acid score, \%;

$n$ - the quantity of essential amino acids - 8 .

Clinical usage of the functional effectiveness of the developed gerodietetic product was carried out at the Department of surgery of the State Institution "Ukrainian National Academy of Medical Sciences Institute of Gerontology n. a. D.F. Chebotarev". During the study 2 groups per 18 elderly patients (age 65-82 years) with somatic diseases and injuries were selected. The representatives of the 1 -st group additional to standard nutrition diet had per 2 portions of the developed products in liquid state (in the morning and in the evening) during 10 days. The representatives of the 2-nd group had only standard nutritional diet. The study of the clinical efficacy of the developed product for enteral nutrition was carried out on a set of indicators, which included studies of the general, in particular physical and psycho-emotional, well-being of patients, total protein level in blood.

Statistical processing of the obtained experimental data was made in accordance with the Student's t-test using special computer programme package SPSS Statistics vs. 20. Average quantity, standard deviation, standard deviation error were calculated. The statistically significant level was considered, its value was less than $5 \%$.

\section{Results and their discussion}

The main factor that makes it possible to evaluate the nutritional, especially energy, value of products for enteral nutrition is the content of macronutrients. Because of it, the content of macronutrients was researched also for establishing the conformity of the researched products to the needs of the target contingent of consumers (older adults). The obtained results are presented in Table 1. 
The content of macronutrients in dry soluble products, $\mathrm{g} / \mathbf{1 0 0} \mathrm{g}$

\begin{tabular}{|l|c|c|}
\hline \multicolumn{1}{|c|}{ Macronutrients } & Control sample & Developed product \\
\hline Proteins & $18.49 \pm 0.21$ & $18.18 \pm 0.26$ \\
\hline Lipids & $17.79 \pm 0.15$ & $11.82 \pm 0.12$ \\
\hline Carbohydrates & $56.81 \pm 0.48$ & $62.08 \pm 0.44$ \\
\hline
\end{tabular}

The obtained experimental data about the content of macronutrients allows concluding that the developed product for enteral nutrition is characterized by a high content of protein component. This is due to the fact that proteins have the specific metabolic effects, which are explained by special metabolic activity of these products on the human body (recovery of protein losses, provision of plastic material for muscles and bones).
Using the results about the ratio of macronutrients in the developed gerodietetic product for enteral nutrition it can be stated that it meets the analyzed specific needs of the elder people in the main food substrates [6; 8-16].

The research results of amino acids qualitative and quantitative composition are presented in Table 2.

The amino acids composition of products for enteral nutrition, $\mathrm{mg} / \mathrm{g}$ of crude protein

Table 2

\begin{tabular}{|c|c|c|}
\hline \multirow{2}{*}{ Amino acids name } & \multicolumn{2}{|c|}{ Products content, mg/g of crude protein } \\
\hline & Control sample & Developed product \\
\hline \multicolumn{3}{|l|}{ Essential amino acids } \\
\hline Isoleucine & $45.8 \pm 2.2$ & $46.8 \pm 2.6$ \\
\hline Lysine & $65.6 \pm 3.1$ & $67.8 \pm 3.2$ \\
\hline Leucine & $79.4 \pm 3.8$ & $72.4 \pm 3.4$ \\
\hline Methionine & $22.5 \pm 0.9$ & $28.6 \pm 1.7$ \\
\hline Threonine & $48.1 \pm 2.2$ & $51.1 \pm 2.7$ \\
\hline Tryptophan & $14.4 \pm 0.6$ & $16.9 \pm 0.8$ \\
\hline Phenylalanine & $27.9 \pm 1.2$ & $32.3 \pm 1.4$ \\
\hline Valine & $57.3 \pm 2.3$ & $52.5 \pm 2.2$ \\
\hline $\begin{array}{c}\text { Total } \\
\end{array}$ & $361.0 \pm 16.3$ & $368.4 \pm 18.2$ \\
\hline \multicolumn{3}{|c|}{ Conditionally essential amino acids } \\
\hline Cystine & $13.5 \pm 0.7$ & $10.4 \pm 0.5$ \\
\hline Tyrosine & $25.7 \pm 1.1$ & $26.4 \pm 1.2$ \\
\hline $\begin{array}{r}\text { Total } \\
\end{array}$ & $39.2 \pm 1.8$ & $36.8 \pm 1.7$ \\
\hline \multicolumn{3}{|l|}{ Nonessential amino acids } \\
\hline Alanine & $46.1 \pm 2.1$ & $47.4 \pm 1.8$ \\
\hline Arginine & $39.5 \pm 1.8$ & $29.8 \pm 0.7$ \\
\hline Asparagine acid & $107.5 \pm 5.1$ & $103.4 \pm 4.3$ \\
\hline Glycine & $21.0 \pm 0.9$ & $21.1 \pm 0.6$ \\
\hline Glutamine & $237.1 \pm 11,0$ & $261,4 \pm 11,8$ \\
\hline Histidine & $34.7 \pm 1,2$ & $15,7 \pm 0,6$ \\
\hline Ornithine & \multicolumn{2}{|c|}{ Traces } \\
\hline Proline & $64.0 \pm 2,9$ & $63,8 \pm 2,4$ \\
\hline Serine & $49.9 \pm 1,8$ & $51,9 \pm 1,9$ \\
\hline Total & $599.8 \pm 26,8$ & $594,5 \pm 24,1$ \\
\hline
\end{tabular}

Basing on the results of conducted study the amino acid score was researched. The obtained data are presented in Table 3.

Table 3

Amino acids score of the developed product for enteral nutrition

\begin{tabular}{|c|c|c|c|c|c|}
\hline \multirow{2}{*}{ Essential amino acids } & \multirow{2}{*}{ FAO/WHO scale } & \multicolumn{2}{|c|}{ Control sample } & \multicolumn{2}{|c|}{ Developed product } \\
\hline & & mg/g crude protein & score, $\%$ & $\mathrm{mg} / \mathrm{g}$ crude protein & score, \% \\
\hline Isoleucine & 40 & 45.8 & 114.5 & 46.8 & 117.0 \\
\hline Lysine & 55 & 65.6 & 119.3 & 67.8 & 123.3 \\
\hline Leucine & 70 & 79.4 & 113.4 & 72.4 & 103.4 \\
\hline Methionine + cystine & 35 & 36.0 & 102.9 & 39.0 & 111.4 \\
\hline Threonine & 40 & 48.1 & 120.3 & 51.1 & 127.8 \\
\hline Tryptophan & 10 & 14.4 & 144.0 & 16.9 & 169.0 \\
\hline $\begin{array}{l}\text { Phenylalanine + } \\
\text { tyrosine }\end{array}$ & 60 & 53.6 & 89.3 & 58.7 & 97.8 \\
\hline Valine & 50 & 57.3 & 114.6 & 52.5 & 105.0 \\
\hline Total & - & 409.6 & - & 405.2 & - \\
\hline
\end{tabular}


Journal of Chemistry and Technologies, 2020, 28(2), 161-167

The data, presented in Table 3, prove the fact that the proteins of the developed gerodietetic product for enteral nutrition are characterized by high biological value of protein component. It is explained by balanced essential amino acids composition. The dominant amino acid of the developed product is tryptophan (159.0\%); limited ones - phenylalanine and tyrosine (97.8\%). For the control sample dominant and limiting amino acids were also mentioned ones (144.0\% and $89.3 \%$ relevantly). These core of amino acids for the gerodietetic product was higher (on $14.8 \%$ and $8.7 \%$ respectively). Improvement of the amino acid composition can be explained by the usage of protein-based whey concentrate WPC-80 of high biological value in the developed product and the partial usage of plant origin proteins in the control one.

At the same time, the products proteins amino acid score calculation doesn't give a complete evaluation of their biological value. The human body requires proteins as a plastic material only in measures of limiting amino acids, in other case they are spent to meet energy needs. That is why for receiving an additional information the proteins biological value was assessed using the amino acid score difference factor (AASDF). The received results are presented in Table 4.

Table 4

The biological value of products for enteral nutrition protein component, $\%$

\begin{tabular}{|l|c|c|c|}
\hline \multicolumn{1}{|c|}{ Index } & Master sample & Control sample & Developed product \\
\hline $\begin{array}{l}\text { The amino acid score difference } \\
\text { factor (AASDF) }\end{array}$ & 0 & 25.4 & 21.5 \\
\hline Biological value & 100 & 74.6 & 78.5 \\
\hline
\end{tabular}

Basing on the received results it was found that the developed gerodietetic dry soluble product's for enteral nutrition amino acid score difference factor (AASDF) was $21.5 \%$. It was on $15.3 \%$ less than the corresponding index of the control sample. As a result, the biological value of the developed product's protein part is on $3.9 \%$ higher than the corresponding index of the control sample.
The results of the developed product's clinical approbation give an opportunity to state that the patients consumed it in a ready-to-drink liquid state with moderate pleasure. Allergies and undesirable effects were not detected.

Obtained results showed that the patients, who consumed the product, had quicker normalization of total protein level in blood than the patients in the control group (Table 5).

Table 5

The results of clinical usage of the gerodietetic product for enteral nutrition

\begin{tabular}{|l|l|c|c|c|}
\hline \multirow{2}{*}{ Index } & \multicolumn{2}{|c|}{ Control group } & \multicolumn{2}{c|}{ Developed group } \\
\cline { 2 - 5 } & $\begin{array}{c}\text { the beginning of } \\
\text { study }\end{array}$ & the end of study & $\begin{array}{c}\text { the beginning of } \\
\text { study }\end{array}$ & the end of study \\
\hline Protein level in blood & $\mathrm{N}^{*}-(20-25 \%)$ & $\mathrm{N}^{*}-(12-14 \%)$ & $\mathrm{N}^{*}-(20-25 \%)$ & $\mathrm{N}^{*}-(8-9 \%)$ \\
\hline
\end{tabular}

where $N^{*}$ - lower level of total protein level in blood according to the laboratory of State Institution «Ukrainian National Academy of Medical Sciences Institute of Gerontology n. a. D.F. Chebotarev».

The conducted study of gerodietetic product's clinical usage allow to confirm that persons, who consumed it, in comparison with the representatives of the control group, had more pronounced tendencies to the improvement of physical and psycho-emotional state. In particular, the total protein level in blood was normalized faster (on 33.3-35.7\%), the period of staying in the hospital (on 12-15\%), treatment and rehabilitation were reduced. It is expected that first of all this fact is substantiated by the biological value of protein component.

\section{Conclusion}

Based on the results of provided assessment of the developed gerodietetic product for enteral nutrition protein's component (including comparing with the control sample) its high nutritional and biological value was determined: the macronutrients content was in accordance with the norms, recommended for the representatives of the older age groups, the amino acids composition was enough balanced, the assessed biological value of its protein component was rather high (78.5\%). Also usage effectiveness and protein's component high biological value were proved by the results of clinical approbation. Through this process, the developed gerodietetic product for enteral nutrition can be recommended for consumption by representatives of the older age groups with high physiological and psychoemotional loads, metabolic dysfunctions, disorders and injuries.

The further researches prospects are the evaluation and detailed analysis of the developed gerodietetic product's food, especially biological, value, in particular the content of fatty acids, 
vitamins, mineral elements and their digestibility by human organism.

\section{Bibliography}

[1] Nutrition and development: a global challenge. [Електронний ресурс]. - Режим доступу: http://www.fao.org/3/u9920t/u9920t07.htm

[2] Enteral Nutrition Market Report. [Електронний ресурс]. - Режим доступу: http://www.nutritioncare.org/ENMarketReport/

[3] Towards a European Food and Nutrition Policy. [Електронний ресурс]. - Режим доступу: https://edepot.wur.nl/423602

[4] Bhandalkar Sh. Enteral Nutrition Market Overview and Forecast to 2025 / Sh. Bhandalkar, T. Kunzel. - N.-Y. : BG Company, 2018. - 89 p.

[5] Нездолій А. Маркетингові дослідження очікувань цільової аудиторії споживачів продуктів із функціональною направленістю / А. Нездолій, Д. Антюшко // Восточно-европейский журнал передовых технологий. - 2015. - №11 (77). - С. 2630.

[6] Григоров Ю.Г. Питание после шестидесяти / Ю.Г. Григоров, С.Г. Козловская - К. : Знання, 1985. - 48 с.

[7] Чеботарев Д.Ф. Слово о старости / Д.Ф. Чеботарев. М. : Знание, 1992. - 64 с.

[8] Смолянський Б.Л. Справочник по лечебному питанию для диет-сестер и поваров / Б.Л. Смолянський, Ж.И. Абрамова. - Л. : Медицина, 1984. -304 c.

[9] Притульська Н. Критерії розробки харчових продуктів геродієтичного призначення / $\mathrm{H}$. Притульська, Д. Антюшко // Товари і ринки. - 2016. - №2 (22). - С. 83-92.

[10] Антюшко Д.П. Биологическая активность композиции с глюкозамином в питании крыс при моделировании повреждений хрящевой и соединительной тканей / Д.П. Антюшко, А.О. Нездолий // Вопр. питания. - 2016. - Т. 25. № 2. С. 72-75.

[11] Погожева А.В. Значение макро- и микроэлементов пищи в оптимизации минеральной плотности костной ткани / А.В. Погожева // Consilium Medicum. - 2015. - № 2. - C. 61-65.

[12] Пузин С.Н. Оптимизация питания пожилых людей как средство профилактики преждевременного старения / С.Н. Пузин, А.В. Погожева, Потапов // Вопр. питания. - 2018. - Т. 87, № 4. - С. 69-77.

[13] Amarantos E. Nutrition and quality of life in older adults / Amarantos E., Martinez A., Dwyer J. // J Gerontol A Biol Sci Med Sci. - 2001. - №2. - C. 54-64.

[14] Guiroz Y. Recommended dietary allowances (RDA) for elderly / Y. Guiroz. - Paris : ULI, 2008. - 143 p.

[15] Morley J.E. Geriatric nutrition / J.E. Morley, D.R. Thomas. - N.-Y. : CRC Press, 2007. - 590 p.

[16] Nutrition for older persons. World Health Organization programs. [Електронний ресурс]. - Режим доступу: http://www.who.int/nutrition/topics/ageing/en/inde x1.html.

[17] Ahmed T. Assessment and management of nutrition in older people and its importance to health / T. Ahmed, N. Haboubi // Clin. Interv Aging. - 2010. - №9. - P. 207216.

[18] Патент 116754 Україна. МПК A23L 33/19б А61К 31/00. Суміш для ентерального харчування геродієтичного призначення / Притульська Н.В., Карпенко П.О., Антюшко Д.П., Гавалко Ю.В. Заявник та патентоутримувач Київський національний

торговельно-економічний університет. -
№г201609484, заяв. 14.09.2016, опубл. 12.06.2017. Бюл. № 11.

[19] James R. Instruction manual single-column amino acid analysis / R. James, Ph. Benson. - California : Durrum Chemical Corporation Printed, 1976. -35 p.

[20] Козаренко Т.Д. Ионообменная хроматография аминокислот (Теоретические основы и практика) / Т.Д. Козаренко, С.Н. Зуев, Н.Ф. Муляр. - Новосибирск : Наука. Сиб. отд-ние, 1981. - 160 с.

[21] Dietary protein quality evaluation in human nutrition: report of an FAO Expert Consultation (1985). [Електронний ресурс]. - Режим доступу: http://www.fao.org/ag/humannutrition/3597802317b979a686a57aa4593304ffc17f06.pdf

[22] Protein and amino acid requirements in human nutrition : report of a joint FAO/WHO/UNU expert consultation. [Електронний ресурс]. - Режим доступу:

https://apps.who.int/iris/handle/10665/43411

[23] Wolfe R. Protein quality as determined by the Digestible Indispensable Amino Acid Score: evaluation of factors underlying the calculation / R. Wolfe, S. Rutherfurd, I. Kim, P. Moughan Nutr Rev. [Електронний ресурс]. Режим https://pubmed.ncbi.nlm.nih.gov/27452871/

[24] Антюшко Д.П. Оценка пищевой ценности продуктов для энтерального питания / Д.П. Антюшко, Ю.В. Гавалко // Вопр. питания. - 2019. - Т. 88. № 5. C. 63-71.

[25] Рогов И.А. Химия пищи / И.А. Рогов, Л.В. Антипова, Н.И. Дунченко. М. : КолосС, 2007. - 853 с.

[26] Толстогузов В.Б. Новые формы белковой пищи (Технологические проблемы и перспективы производства) / В.Б. Толстогузов. - М.: Агропромиздат, 1987. - 303 с.

\section{References}

[1] Nutrition and development: a global challenge. http://www.fao.org/3/u9920t/u9920t07.htm

[2] Enteral Nutrition Market Report. http://www.nutritioncare.org/ENMarketReport/

[3] Towards a European Food and Nutrition Policy. https://edepot.wur.nl/423602

[4] Bhandalkar Sh., Kunzel T. (2018). Enteral Nutrition Market Overview and Forecast to 2025. N.-Y., USA : BG Company.

[5] Нездолій А., Антюшко Д. [Marketing researches of productswitt functional direction target consumer audience]. Eastern-European Journal of Enterprise Technologies. 2015; №11 (77); 26-30. (in Ukrainian). https://doi.org/10.15587/1729-4061.2015.51073

[6] Hryhorov Yu.H., Kozlovskaia S.H. (1985). [Nutrition after sixty]. Kyiv, Ukraine: Knowledge (in Russian).

[7] D.F. Chebotarev (1992). [A word about old age]. Moscow, Russian Federation: Knowledge (in Russian).

[8] Smolianskyi B.L. Abramova Zh.Y. (1984). [Health nutrition guide for dieters and chefs]. Leningrad, Russian Federation: Medicine (in Russian).

[9] Притульська Н., Антюшко Д. [Criteria for the development of older adults food products]. Commodities and markets. 2016; №2 (22); 83-92. (in Ukrainian). http://nbuv.gov.ua/U]RN/tovary 2016212

[10] Антюшко Д.П., Нездолий А.O. [The biological activity of the composition with glucosamine in the diet of rats in the modeling of cartilage and connective tissue damage]. Questions of Nutrition. 2016; 25 (2); 72-75. (in 
Journal of Chemistry and Technologies, 2020, 28(2), 161-167

Russian). https://doi.org/10.24411/0042-8833-2017$\underline{00023}$

[11] Погожева A.B. [The importance of macro and micronutrients of food in optimizing the mineral density of bone fabric]. Consilium Medicum. 2015; №2; 61-65. (in Russian). https://cyberleninka.ru/article/n/znachenie-makro-imikroelementov-pischi-v-optimizatsii-mineralnoyplotnosti-kostnoy-tkani/viewer

[12] Пузин С.Н., Погожева А.В., Потапов В.Н. [Optimization of elderly people nutrition as a means of preventing premature aging]. Questions of Nutrition. 2018; 87 (4); 69-77. (in Russian). https://doi.org/10.24411/00428833-2018-10044

[13] Amarantos E., Martinez A., Dwyer J. Nutrition and quality of life in older adults. J Gerontol A Biol Sci Med Sci. 2001; №2; 54-64. https://doi.org/10.1093/gerona/56.suppl 2.54

[14] Guiroz Y. (2008). Recommended dietary allowances (RDA) for elderly. Paris, France: ULI.

[15] Morley J.E., Thomas D.R. (2007). Geriatric nutrition. N.Y., USA: CRC Press.

[16] Nutrition for older persons. World Health Organization programs.

$\underline{\text { http://www.who.int/nutrition/topics/ageing/en/inde }}$ x1.html.

[17] Ahmed T., Haboubi N. (2010). Assessment and management of nutrition in older people and its importance to health. Clin. Interv Aging, №9, 207-216. https://doi.org/10.2147/CIA.S9664

[18] Prytulska N., Karpenko P., Antiushko D., Havalko Yu. (2017). Ukraine Patent №116754. Kyiv, Ukraine. Kyiv National University of trade and economics.
[19] James, R., Benson Ph. (1976). [Instruction manual single-column amino acid analysis]. California, USA: Durrum Chemical Corporation Printed.

[20] Kozarenko T.D., Zuev S.N., Muliar N.F. (1981). [Ion exchange chromatography of amino acids (Theoretical background and practice)]. Novosibirsk, Russian Federation: Science. Sib. department (in Russian).

[21] Dietary protein quality evaluation in human nutrition: report of an FAO Expert Consultation (1985). http://www.fao.org/ag/humannutrition/3597802317b979a686a57aa4593304ffc17f06.pdf

[22] Protein and amino acid requirements in human nutrition : report of a joint FAO/WHO/UNU expert consultation.

https://apps.who.int/iris/handle/10665/43411

[23] Wolfe R., Rutherfurd S., Kim I., Moughan P. Protein quality as determined by the Digestible Indispensable Amino Acid Score: evaluation of factors underlying the calculation. Nutr Rev. https://pubmed.ncbi.nlm.nih.gov/27452871/

[24] Antiushko D.P., Havalko Yu.V. [Evaluation of the nutritional value of products for enteral nutrition]. Questions of Nutrition. 2019; 88 (5); 63-71. (in Russian) https://www.doi.org/10.24411/0042-8833-2019$\underline{10055}$

[25] Rohov Y.A., Antypova L.V., Dunchenko N.Y. (2007). [Chemistry of food]. Moscow, Russian Federation: KolosS (in Russian).

[26] Tolstohuzov V.B. (1987). [New forms of protein food (Technological problems and production prospects)]. Moscow, Russian Federation: Agropromizdat (in Russian). 